\title{
PREVALENCE OF BARRETT'S ESOPHAGUS IN INDIVIDUALS WITHOUT TYPICAL SYMPTOMS OF GASTROESOPHAGEAL REFLUX DISEASE
}

\author{
Mauro Carneiro de FREITAS, Luciana Dias MORETZSOHN and Luiz G. V. COELHO
}

\begin{abstract}
Background - Barrett's esophagus, the major risk factor for esophageal adenocarcinoma, is detected in approximately $10 \%$ $14 \%$ of individuals submitted to upper endoscopy for the assessment of gastroesophageal reflux disease related symptoms. Prevalence studies of Barrett's esophagus in individuals without typical symptoms of gastroesophageal reflux disease have reported rates ranging from $0.6 \%$ to $25 \%$. Aim - To determine the prevalence of Barrett's in a Brazilian population older than 50 years without typical symptoms of gastroesophageal reflux disease. Methods - A total of 104 patients (51 men), mean age of 65 years, with an indication for upper endoscopy but without symptoms of heartburn and/or acid regurgitation (determined with a validated questionnaire) were recruited. Subjects submitted to upper endoscopic examination in the last 10 years or using antisecretory medication (proton pump inhibitors) during the last 6 months were not included. Methylene blue chromoscopy was performed during the endoscopic exam to facilitate identification of the metaplastic epithelium. Results - Barrett's esophagus was diagnosed endoscopically and confirmed by histology in four patients, all of them males. The metaplastic segment was short (less than $3 \mathrm{~cm}$ ) and free of dysplasia in all patients. The prevalence of Barrett's esophagus was $7.75 \%$ in the male population and 3.8\% in the general population studied. Conclusion - Due to the low prevalence of Barrett's esophagus found in the present study, associated with the finding of short-segment Barrett's esophagus in all cases diagnosed and the absence of dysplasia in the material analyzed, endoscopic screening for Barrett's esophagus in patients above the age of 50 without the classical symptoms of gastroesophageal reflux disease is not indicated for the Brazilian population.
\end{abstract}

HEADINGS - Barrett esophagus. Gastroesophageal reflux. Endoscopy, gastrointestinal.

\section{INTRODUCTION}

Barrett's esophagus (BE) is possible complication of long standing gastroesophageal reflux disease (GERD), and it is considered the main risk factor for esophageal $\operatorname{adenocarcinoma~}^{(26)}$.

An increasing incidence of esophageal adenocarcinoma has been reported, mainly in white male individuals. The incidence of progression of Barrett's esophagus to adenocarcinoma, as well as the cost-benefit ratio of routine endoscopic monitoring programs in this group of patients, is poorly defined ${ }^{(12)}$. New diagnostic procedures such as chromoscopy and magnification endoscopy have been increasingly used to permit higher accuracy in the diagnosis of Barrett's esophagus ${ }^{(7,20)}$.

It is estimated that an expressive number of patients with Barrett's esophagus progress without symptoms of GERD, or present symptoms at an intensity that does not encourage them to seek medical care. Studies conducted on autopsy material ${ }^{(5)}$ and on asymptomatic subjects ${ }^{(15)}$ have demonstrated an increasing prevalence of Barrett's esophagus when compared to those diagnosed on an eminently clinical basis.

Once the diagnosis of Barrett's esophagus has been established, periodic endoscopic monitoring of the patients is recommended ${ }^{(29)}$.

The variations in the incidence of Barrett's esophagus in different clinical contexts and populations, associated to increased incidence of esophageal adenocarcinoma, even in the absence of previous diagnosis of Barrett's esophagus, have encouraged studies aimed at identifying the presence of Barrett's esophagus among asymptomatic individuals in a risk population ${ }^{(15,27,33)}$.

A better understanding of the prevalence of Barrett's esophagus in the Brazilian risk population may provide important information for the establishment of management strategies and norms directed at the Brazilian population regarding this relevant disease. 


\section{METHODS}

The study was conducted at the Alfa Institute of Gastroenterology of the University Hospital, Federal University of Minas Gerais, Belo Horizonte, MG, Brazil, and the protocol was approved by the Research Ethics Committee of this institution. All subjects received detailed information about the study and only those who agreed to participate and signed a free informed consent form were included.

A total of 104 patients with an indication for upper endoscopic evaluation who met the following criteria were recruited: 1) minimum age of 50 years; 2) absence of classical symptoms of GERD (acid regurgitation and/or heartburn) confirmed using a validated GERD-Health-Related Quality of Life questionnaire ${ }^{(13)}$; and 3 ) indication for upper endoscopy due to signs or symptoms not related to reflux esophagitis (anemia, nonspecific dyspeptic symptoms, abdominal pain, swallowing alterations, weight loss, and chest pain, among others).

Exclusion criteria were: 1) patients submitted to previous upper gastrointestinal tract surgeries, except cholecystectomy; 2) patients with severe neuropsychiatric disorders; 3 ) patients with a history of upper endoscopy in the last 10 years; and 4) patients using proton pump inhibitors and/or $\mathrm{H} 2$ receptor antagonists during the last 6 months.

All participants were submitted to upper endoscopy performed by the same endoscopist using a 201EX videoendoscope (Fujinon, Japan).

For the exam, the patients were monitored and sedated with midazolam (mean dose of $3 \mathrm{mg}$ ) and meperidine (mean dose of $25 \mathrm{mg}$ ) after topical oral anesthesia with lidocaine spray. To facilitate investigation of Barrett's esophagus, direct methylene blue chromoendoscopy was performed using catheter spray according to the following protocol: $5 \mathrm{~mL} 10 \% \mathrm{~N}$-acetylcysteine solution was instilled in the lower third of the esophagus, followed by the instillation of 5 to $10 \mathrm{~mL} 0.5 \%$ methylene blue solution. After $2 \mathrm{~min}$, 20 to $30 \mathrm{~mL}$ water was instilled to wash the distal esophagus and to identify methylene blue-stained areas that might correspond to a segment of BE. During the exam, two biopsy fragments were collected from the gastric body and antrum as part of the protocol of our service. If the presence of BE was suspected, additional biopsy specimens were collected from any segment of the glandular epithelium extending above the esophagogastric junction in the four quadrants at $1 \mathrm{~cm}$ intervals.

The patients were classified according to the endoscopic findings as follows: esophagus with intact mucosa, erosive esophagitis grade A, B, C or D of the Los Angeles classification ${ }^{(2)}$, and Barrett's esophagus.

\section{Histological analysis}

Intestinal metaplasia was recorded as present or absent and confirmed in all cases by Alcian blue staining, $\mathrm{pH} 2.5$. If present, dysplasia was determined with the use of a standardized classification as defined by RIDDELL et al. ${ }^{(28)}$. The fragments collected in gastric body and antrum were stained with hematoxylin-eosin for histopathologic examination of presence of $H$. pylori infection.

\section{Statistical analysis}

The results were analyzed statistically by the chi-square test and Fisher's exact test. The level of significance was set at $\alpha=0.05$ in all tests.

\section{RESULTS}

A total of 104 patients, including 51 (49\%) men and $53(51 \%)$ women, were selected. Patient age ranged from 51 to 92 years, with a mean ( \pm standard deviation) of $65 \pm 10.2$ years. Eightynine $(85.6 \%)$ patients were classified as white and $15(14.4 \%)$ as non-white. The main indications of upper endoscopy for the participants were investigation of abdominal pain, swallowing alterations, chronic phlegm, weight loss, anemia, a positive fecal occult blood test, and chest pain.

Ninety-one $(87.5 \%)$ patients presented an esophagus with intact mucosa and nine (8.7\%) had erosive esophagitis (five categorized as grade $\mathrm{A}$ and four as grade $\mathrm{B}$ according to Los Angeles classification). The presence of $H$. pylori infection was detected in $47(45.2 \%)$ patients and hiatal hernia in $23(22.1 \%)$. Eighty-nine $(85.6 \%)$ patients had never undergone digestive endoscopy and $15(14.4 \%)$ had been submitted to the exam more than 10 years ago. Direct methylene blue chromoscopy led to a suspicion of metaplastic epithelium in six patients. The presence of intestinal metaplasia was confirmed histologically in four patients, all of them males and three of them white. The length of these segments ranged form 0.5 to $1.5 \mathrm{~cm}$. No association was observed between erosive esophagitis and gender, although the finding of an intact esophageal mucosa was significantly associated with female gender (Table 1).

TABLE 1. Association between the endoscopic findings and gender in the 104 patients of the study

\begin{tabular}{|c|c|c|c|}
\hline \multirow{2}{*}{ Endoscopic findings } & \multicolumn{2}{|c|}{ Gender } & \multirow{2}{*}{$P$ value* } \\
\hline & Male & Female & \\
\hline \multicolumn{4}{|l|}{ Barrett's esophagus } \\
\hline Yes & 4 & 0 & \multirow{2}{*}{0.0543} \\
\hline No & 47 & 53 & \\
\hline \multicolumn{4}{|l|}{ Erosive esophagitis } \\
\hline Yes & 6 & 3 & \multirow{2}{*}{0.3146} \\
\hline No & 45 & 50 & \\
\hline \multicolumn{4}{|l|}{ Intact mucosa } \\
\hline Yes & 41 & 50 & \multirow{2}{*}{$0.0397 * *$} \\
\hline No & 10 & 3 & \\
\hline \multicolumn{4}{|l|}{ Hiatal hernia } \\
\hline Yes & 10 & 13 & \multirow{2}{*}{0.6390} \\
\hline No & 41 & 40 & \\
\hline
\end{tabular}

No significant association was observed between endoscopic findings (presence of hiatal hernia and esophageal alterations) and patient race or the presence of $H$. pylori infection.

\section{DISCUSSION}

Barrett's esophagus is frequently identified in adult patients in the sixth decade of life, during upper endoscopic examination ${ }^{(32)}$. 
The absence of reflux symptoms does not rule out the possibility of a diagnosis of Barrett's esophagus. WINTERS et al. ${ }^{(37)}$ detected the presence of Barrett's esophagus in $12.4 \%$ of the population studied and found no correlation between symptoms and the presence of intestinal metaplasia, especially among patients above the age of 50 .

Expressive differences in the prevalence of Barrett's esophagus have been reported in patients submitted to upper endoscopic examination for various indications. In Japan, where adenocarcinoma is responsible for less than $5 \%$ of all esophageal cancers, the prevalence of BE ranges from $0.3 \%$ to $0.6 \%$ in the general population and is present in $15.7 \%$ of individuals submitted to endoscopy for the assessment of this disease ${ }^{(3)}$. Although Barrett's esophagus is not common in Africa or the Middle East, a prevalence of $8.4 \%$ and $7.4 \%$ has been reported in Jordan and Turkey, respectively. In China, the prevalence of BE was $2 \%$ in a group of 464 Chinese patients submitted to upper endoscopy. In Italy, this prevalence was $2 \%$ in patients with symptoms of GERD and $0.6 \%$ in asymptomatic patients ${ }^{(33)}$. In the United States, GERSON et al. ${ }^{(15)}$ detected Barrett's esophagus in $25 \%$ of asymptomatic Caucasian patients older than 50 years who underwent colonoscopy for colorectal cancer screening. In a Mayo Clinic study ${ }^{(33)}$ the prevalence of Barrett's esophagus was $24.1 \%$ among individuals with symptoms of GERD and 15.4\% among asymptomatic patients who were scheduled for colonoscopy. In Brazil, CAUM et al. ${ }^{(8)}$ reported a prevalence of $18.4 \%$ among symptomatic patients, FAGUNDES et al. ${ }^{(11)}$ found a prevalence of $2,5 \%$ in 1,276 patients submitted to upper endoscopy and ANDREOLLO et al..$^{(1)}$ showed prevalence of 3,57\% among patients with esophagitis and $0,53 \%$ in general population.

The prevalence of Barrett's esophagus observed in the present study, $3.8 \%$ in the general population and $7.75 \%$ in the male population, was lower than those reported in other studies, especially North American ones. These differences might be explained by the characteristics of the study participants. Some of those studies have been conducted on a mainly Caucasian and male population, whereas the present population was miscegenous and more homogenous in terms of gender. Although the etiology of Barrett's esophagus has not been completely established, possible risk factors include the frequency and duration of GERD symptoms, the presence and size of hiatal hernia, degree of lower esophageal sphincter incompetence, and alkaline or mixed gastroduodenal reflux ${ }^{(6,18,19,21)}$. Although none of these factors is related to gender, male gender is also considered to be a risk factor for Barrett's esophagus, with a proportion higher than 2:1 in most series. The reasons for this disparity remain obscure. BANKI et al. ${ }^{(4)}$ compared risk factors for Barrett's esophagus between men and women. The authors observed that the only risk factor related to Barrett's esophagus in both genders is an increased exposure to bilirubin and identified no specific protective factor among women with this disease. In contrast, in patients with non-complicated forms of GERD a lower esophageal acid exposure was observed among women, a fact that would explain the present finding of a higher prevalence of intact esophageal mucosa among female subjects.

The association of Barrett's esophagus and esophageal adenocarcinoma with Caucasian race has been confirmed since the $1980 \mathrm{~s}^{(31)}$. The requirement of the presence of intestinal metaplasia for the diagnosis of Barrett's esophagus has led to an even further increase in the predominance of its diagnosis among Caucasians. In different series, $90 \%$ to $100 \%$ of patients with $\mathrm{BE}$ are Caucasians ${ }^{(9,16,35,36)}$. SHARMA et al. ${ }^{(30)}$ also recognized Caucasian race in $96 \%$ of 95 patients with shortsegment Barrett's esophagus. In the present study, the presence of Barrett's esophagus showed a proportion of $3: 1$ for white and non-white subjects.

The diagnosis of short Barrett's esophagus might be overlooked if the esophagogastric junction is not carefully examined and if the biopsies are not correct targeted. The study of PADDA and RAMIREZ ${ }^{(23)}$ showed a histological confirmation of long- and short-segment Barrett's esophagus in $75 \%$ and $38.4 \%$ of cases, respectively. Among the six cases suspected macroscopically in the present study, four $(66.6 \%)$ were confirmed by histology. All of them presented short-segment Barrett's esophagus with a homogenous pattern upon chromoscopy ranging in length from 0.5 to $1.5 \mathrm{~cm}$. JONES et al. ${ }^{(17)}$, reevaluating patients with an endoscopic suspicion of short-segment Barrett's esophagus but without histological confirmation, obtained diagnostic confirmation after a second exam in $23.2 \%$ of cases. In the present study, the two suspected cases not confirmed histologically were not submitted to endoscopic reassessment.

The correct characterization of short segments has become more complex after the description of intestinal metaplasia in cardia, which can be associated to GERD or H.pylori infection ${ }^{(14,22)}$. Histopathological analysis is sometimes unable to distinguish between the three metaplastic conditions that can occur at the esophagogastric junction, i.e., carditis accompanied by intestinal metaplasia related to $H$. pylori infection, carditis accompanied by intestinal metaplasia related to GERD, and short-segment Barrett's esophagus.

The risk of malignant transformation of metaplastic segments shorter than $1.0 \mathrm{~cm}$ is not well defined, but might be lower due to the extent of the metaplastic epithelium exposed to damaging agents. These divergences have been discussed in the literature, with emphasis on these types of metaplasia in the oncogenesis of adenocarcinomas of the esophagogastric junction ${ }^{(10,25,34)}$.

The large number of studies published over the last years investigating the relationship between GERD, esophagitis, H. pylori, carditis, Barrett's esophagus and the presence of junctional intestinal metaplasia had only a single implicit or explicit objective, i.e., to obtain information that would permit to reduce the increasing incidence of adenocarcinomas of the esophagogastric junction observed over the last two decades ${ }^{(24)}$.

\section{CONCLUSION}

We suggest that, due to the low prevalence of BE found in the present study (3.8\%), associated with the finding of short-segment Barrett's esophagus in all cases diagnosed and the absence of dysplasia in the material analyzed, endoscopic screening for BE in patients above the age of 50 without the classical symptoms of GERD is not indicated for the Brazilian population. Further studies involving a larger number of patients are necessary to confirm the present findings. 
Freitas MC, Moretzsohn LD, Coelho LGV. Prevalência do esôfago de Barrett em indivíduos sem sintomas típicos da doença por refluxo gastroesofágico. Arq Gastroenterol. 2008;45(1):46-9.

RESUMO - Racional - O esôfago de Barrett, principal fator de risco para o adenocarcinoma do esôfago, é uma complicação da doença por refluxo gastroesofágico de longa duração, sendo detectado em, aproximadamente, $10 \%-14 \%$ dos indivíduos submetidos a endoscopia digestiva alta para avaliação de sintomas relacionados à doença por refluxo gastroesofágico. Estudos de prevalência do esôfago de Barrett em indivíduos sem sintomas típicos de doença por refluxo gastroesofágico mostram taxas oscilando entre $0,6 \%$ e $25 \%$. Objetivo - Determinar a prevalência do esôfago de Barrett em indivíduos maiores de 50 anos sem os sintomas clássicos da doença por refluxo gastroesofágico. Métodos - Foram recrutados 104 pacientes (51 homens e 53 mulheres), idade média 65 anos, com indicação de se submeterem a endoscopia digestiva alta, porém sem sintomas de pirose e/ou regurgitação ácida (certificados através de questionário validado). Foram excluídos indivíduos com exame endoscópico prévio nos últimos 10 anos ou que fizeram uso de medicação anti-secretora nos últimos 6 meses. Durante o exame endoscópico foi realizada cromoscopia com azul de metileno, para facilitar a identificação do epitélio metaplásico. Resultados - O esôfago de Barrett foi diagnosticado por endoscopia e confirmado pela histologia em quatro pacientes, todos do sexo masculino. Os segmentos metaplásicos eram curtos (inferior a $3 \mathrm{~cm}$ ) e livre de displasia em todos os pacientes. A prevalência encontrada foi de $7,75 \%$ na população masculina e 3,8\% na população geral avaliada. Conclusão - Diante da baixa prevalência do esôfago de Barrett encontrada no presente estudo, associada ao achado de segmento curto de Barrett em todos os casos diagnosticados e ausência de displasia no material analisado, rastreamento endoscópico para o esôfago de Barrett em pacientes acima de 50 anos sem os sintomas clássicos da doença por refluxo gastroesofágico não se justificaria na população brasileira.

DESCRITORES - Esôfago de Barrett. Refluxo gastroesofágico. Endoscopia gastrointestinal.

\section{REFERENCES}

1. Andreollo NA, Michelino MU, Brandalise NA, Lopes LR, Trevisan MA, Leonardi LS. Incidência e epidemiologia do epitélio de Barret no Gastrocentro - UNICAMP. Arq Gastroenterol. 1997;34:22-6.

2. Armstrong D, Bennett JR, Blum AL, Dent J, De Dombal, FT, Galmiche JP1. The endoscopic assessment of esophagitis: a progress report on observer agreement. Gastroenterology. 1996;111:85-92.

3. Azuma N, Endo T, Arimura Y, Motoya S, Itoh F, Hinoda Y. Prevalence of Barrett's esophagus and expression of mucin antigens detected by a panel of monoclonal antibodies in Barrett's esophagus and esophageal adenocarcinoma in Japan. J Gastroenterol. 2000;35:583-92.

4. Banki F, DeMeester SR, Mason RJ, Campos G, Hagen JA, Peters JH. Barrett's esophagus in females: a comparative analysis of risk factors in females and males. Am J Gastroenterol. 2005; 100:560-7

5. Cameron AJ, Zinsmeister AR, Ballard DJ, Carney JA. Prevalence of columnar-lined (Barrett's) esophagus. Comparison of population-based clinical and autopsy findings. Gastroenterology. 1990;99:918-22.

6. Campos GM, DeMeester SR, Peters JH, Oberg S, Crookes PF, Hagen JA. Predictive factors of Barrett esophagus: multivariate analysis of 502 patients with gastroesophageal reflux disease. Arch Surg. 2001;136:1267-73.

7. Canto MI, Yoshida T, Gossner L. Chromoscopy of intestinal metaplasia in Barrett's esophagus. Endoscopy. 2002;34:330-6.

8. Caum LC, Bizinelli SL, Pisani JC, Amarantes HM, Ioshii SO, Carmes ER. Specialized intestinal metaplasia of the distal esophagus in gastroesophageal reflux disease: prevalence and clinico-demographic features. Arq Gastroenterol. 2003;40:220-6.

9. Chalasani N, Wo JM, Hunter JG, Waring JP. Significance of intestinal metaplasia in different areas of esophagus including esophagogastric junction. Dig Dis Sci. 1997;42:603-7.

10. Csendes A, Smok G, Burdiles P, Korn O, Gradiz M, Rojas J. Prevalence of intestinal metaplasia according to the length of the specialized columnar epithelium lining the distal esophagus in patients with gastroesophageal reflux. Dis Esophagus. 2003;16:24-8

11. Fagundes RB, Canterelli Jr JC, Bassi LA, Melo CR, Oliveira VP, Fenili AC, Carli D. Prevalência do esôfago de Barret na unidade de endoscopia digestiva de hospital de referência para a região central do Rio Grande do Sul. Gastroenterol Endosc Dig. 2003;22:213-8.

12. Forman D. Review article: oesophago-gastric adenocarcinoma -- an epidemiological perspective. Aliment Pharmacol Ther. 2004;20 (Suppl 5):55-60; discussion 61-2.

13. Fornari F, Gruber AC, Lopes AB, Cecchetti D, Barros SG. Questionário de sintomas na doença do refluxo gastroesofágico. Arq Gastroenterol. 2004:41:263-7.

14. Genta RM, Huberman RM, Graham DY. The gastric cardia in Helicobacter pylori infection . Hum Pathol. 1994;25:915-9.

15. Gerson LB, Shetler K, Triadafilopoulos G. Prevalence of Barrett's esophagus in asymptomatic individuals. Gastroenterology. 2002;123:461-7.

16. Johnston MH, Hammond AS, Laskin W, Jones DM. The prevalence and clinical characteristics of short segments of specialized intestinal metaplasia in the distal esophagus on routine endoscopy. Am J Gastroenterol. 1996;91:1507-11.

17. Jones TF, Sharma P, Daaboul B, Cherian R, Mayo M, Topalovski M. Yield of intestinal metaplasia in patients with suspected short-segment Barrett's esophagus (SSBE) on repeat endoscopy. Dig Dis Sci. 2002;47:2108-11.

18. Kaur BS, Ouatu-Lascar R, Omary MB, Triadafilopoulos G. Bile salts induce or blun cell proliferation in Barrett's esophagus in an acid-dependent fashion. Am J Physiol Gastrointest Liver Physiol. 2000;278:g1000-9.
19. Martinez de Haro L, Ortiz P, Parrilla P, Munitz V, Molina J, Bermejo J. Intestinal metaplasia in patients with columnar lined esophagus is associated with high levels of duodenogastroesophageal reflux. Ann Surg. 2001;233:34-8.

20. Meining A, Rosch T, Kiesslich R, Muders M, Sax F, Heldwein W. Inter- and intraobserver variability of magnification chromoendoscopy for detecting specialized intestinal metaplasia at the gastroesophageal junction. Endoscopy. 2004;36:160-4.

21. Menges M, Muller M, Zeitz M. Increased acid and bile reflux in Barrett's esophagus compared to reflux esophagitis, and effect of proton pump inhibitor therapy. Am J Gastroenterol. 2001;96:331-7.

22. Nandurkar S, Talley NJ, Martin CJ, Ng TH, Adams S. Short segment Barrett's oesophagus: prevalence, diagnosis and associations. Gut. 1997;40:710-5.

23. Padda S, Ramirez FC. Accuracy in the diagnosis of short-segment Barrett's esophagus: the role of endoscopic experience. Gastrointest Endosc. 2001;54:605-8.

24. Pera M. Epidemiology of esophageal cancer, especially adenocarcinoma of the esophagus and esophagogastric junction. Recent Results Cancer Res. 2000;155:1-14.

25. Pera M. Trends in incidence and prevalence of specialized intestinal metaplasia, Barrett's esophagus, and adenocarcinoma of the gastroesophageal junction. World J Surg. 2003;27:999-1008; discussion 1006-8.

26. Pisegna J, Holtmann G, Howden CW, Katelaris PH, Sharma P, Spechler S. Review article: oesophageal complications and consequences of persistent gastro-oesophagea reflux disease. Aliment Pharmacol Ther. 2004;20 (Suppl 9):47-56.

27. Rex DK, Cummings OW, Shaw M, Cumings MD, Wong RK, Vasudeva RS. Screening for Barrett's esophagus in colonoscopy patients with and without heartburn. Gastroenterology. 2003; 125:1670-7.

28. Riddell RH. Premalignant and early malignant lesions in the gastrointestinal tract: definitions, terminology, and problems. Am J Gastroenterol. 1996;91:864-72.

29. Sampliner RE. Updated guidelines for the diagnosis, surveillance, and therapy of Barrett's esophagus. Am J Gastroenterol. 2002;97:1888-95.

30. Sharma P, Weston AP, Morales T, Topalovski M, Mayo MS, Sampliner RE. Relative risk of dysplasia for patients with intestinal metaplasia in the distal oesophagus and in the gastric cardia. Gut. 2000;46:9-13.

31. Skinner DB, Walther BC, Riddell RH, Schmidt H, Iascone C, DeMeester TR. Barrett's esophagus. Comparison of benign and malignant cases. Ann Surg. 1983;198:554-65.

32. Spechler SJ. Barrett's esophagus. Semin Gastrointest Dis. 1996;7:51-60.

33. Toruner M, Soykan I, Ensari A, Kuzu I, Yurdaydin C, Ozden A. Barrett's esophagus: prevalence and its relationship with dyspeptic symptoms. J Gastroenterol Hepatol. 2004;19:535-40.

34. Voutilainen M, Farkilla M, Juhola M, Nuorva K, Mauranen K, Mantynen T. Specialized columnar epithelium of esophagogastric junction: prevalence and associations. The Central Finland Endoscopy Study Group. Am J Gastroenterol. 1999;94:913-8.

35. Weston AP, Krmpotich P, Makdisi WF, Cherian R, Dixon A, MacGregor DH. Short segment Barrett's esophagus: clinical and histological features, associated endoscopic findings, and association with gastric intestinal metaplasia. Am J Gastroenterol. 1996;91:981-6.

36. Weston AP, BadrAS, Topalovski M, Cherian R, Dixon A, Hassanein RS. Prospective evaluation of the prevalence of gastric Helicobacter pylori infection in patients with GERD, Barrett's esophagus, Barrett's dysplasia, and Barrett's adenocarcinoma. Am J Gastroenterol. 2000;95:387-94.

37. Winters C Jr, Spurling TJ, Chobanian SJ, Curtis DJ, Esposito RL, Hacker JF $3^{\text {rd }}$, Johnson DA, Cruess DF, Cotelingan JD, Gurney MS, et al. Barrett's esophagus. A prevalent, occult complication of gastroesophageal reflux disease. Gastroenterology. 1987;92:118-24

Recebido em 4/6/2007. Aprovado em 6/8/2007. 